\title{
The Effect of Birdsfoot Trefoil (Lotus corniculatus) and White Clover (Trifolium repens) in Mixed Pasture Swards on Incoming and Established Nematode Infections in Young Lambs
}

\author{
By G. Bernes ${ }^{1}$, P. J. Waller ${ }^{2}$ and D. Christensson ${ }^{2}$
}

${ }^{1}$ Department of Agricultural Research for Northern Sweden, Swedish University of Agricultural Sciences, Umeå, ${ }^{2}$ Department of Parasitology (SWEPAR), National Veterinary Institute, Uppsala, Sweden.

\begin{abstract}
Bernes G, Waller PJ, Christensson D: The effect of birdsfoot trefoil (Lotus corniculatus) and white clover (Trifolium repens) in mixed pasture swards on incoming and established nematode infections in young lambs. Acta vet. scand. 2000, 41, 351-361. - Lotus corniculatus L., a leguminous plant containing condensed tannins, is now being evaluated in Sweden as a component of mixed pastures. This is because of its high nutritive value, palatability, modest requirement for water, calcium and phosphorous and particularly because it has the ability to survive harsh weather conditions that typify northern Scandinavia. This trial was undertaken to assess the possible parasitological benefits of using $L$. corniculatus when fed as a minor component in a mixed pasture sward to young sheep. This was compared with similar sheep that were fed pasture with a comparable legume content consisting of Trifolium repens L. Separate groups of lambs, maintained in pens and provided with fresh pasture cuts containing either $L$. corniculatus or $T$. repens each day, were trickle-dosed with infective larvae of mixed parasite species. For each pasture type, groups of 6 lambs had either established worm burdens only, received incoming infections only, or had the combination of both adult and incoming infections. Worm burdens were monitored by serial faecal egg counts and at the termination of the study, all animals were slaughtered for worm recovery, identification and enumeration. The results showed that there were no differential effects between L. corniculatus and T. repens on the different stages of development for a range of nematode parasite species recovered from these lambs. Several reasons may account for this: such as the low level of condensed tannins in the L. corniculatus variety tested, the minor proportion of this plant in the diet and/or the variety of $L$. corniculatus used in this trial which do not provide any benefits to controlling parasites of sheep.
\end{abstract}

condensed tannins; nematode parasites; sheep.

\section{Introduction}

Birdsfoot trefoil, Lotus corniculatus L., is a leguminous plant that contains relatively high concentrations of condensed tannins. This plant species is commonly found throughout temperate areas of the world and it is a useful inclusion in pasture mixes because of its high nutritive value, palatability and modest requirements of water, calcium and phosphorous. An important attribute of $L$. corniculatus is the presence of condensed tannins, which help to safeguard against bloat problems in ruminant livestock (Tanner et al. 1995), when this plant constitutes a significant component of grazed pastures. Some other Lotus species have the same char- 
acteristics, but $L$. corniculatus is of particular interest in Sweden because of its winter-hardiness (Beuselinck \& Grant 1995, NilsdotterLinde 1999). Research is underway to investigate the productivity, competitiveness, overwinter survival and tolerance to grazing pressure of $L$. corniculatus in mixed pasture swards for a number of locations in this country (Nilsdotter-Linde \& Tuvesson 1999, NilsdotterLinde et al. 1999).

Another possible benefit of tanniferous forages may be on reducing the number, or mitigating the effects, of internal parasites in ruminant livestock. Recent works in New Zealand indicate that pasture plants containing moderately high levels of condensed tannins provide young sheep with the ability to withstand parasite infection (Niezen et al. 1994, 1995, Robertson et al. 1995). These works made comparisons between a range of tanniferous forages, including 2 species of Lotus ( $L$. corniculatus and $L$. pedunculatus). Their studies showed parasitological benefits associated with the latter, but not the former species.

It is well recognised that considerable variation exists in levels of condensed tannins in plants, even within species (Lowther et al. 1987, Kelman \& Tanner 1990, Hedqvist et al. 2000). Moreover, these may be modified by age, stage of development and condition of the plant material (Hedqvist 1999, Hedqvist el al. 2000). Therefore, we considered that the rather negative results relating to the lack of protection afforded by $L$. corniculatus in young sheep against parasite infections in the New Zealand studies did not necessarily imply a general phenomenon for all cultivars of $L$. corniculatus grown under different environmental conditions. The large-scale agronomic field evaluations of $L$. corniculatus underway in Sweden (outlined above) provided us with the opportunity to investigate potential parasitological benefits of this plant when fed to young sheep.
The aim of this study was to investigate under Swedish conditions the effects of fresh cuts of pasture ley, one containing $L$. corniculatus and the other containing Trifolium repens $\mathrm{L}$. This latter plant is a legume of comparable nutritive content to $L$. corniculatus, but it lacks condensed tannins. Our investigations were focussed on studying the effects of feeding these pasture swards to young sheep harbouring mixed adult parasite infections and on the establishment of incoming infective larvae in these animals.

\section{Materials and methods}

\section{Pastures}

This study was conducted at the Swedish University of Agricultural Sciences research farm of Röbäcksdalen, Umeå, northern Sweden $\left(63.4^{\circ} \mathrm{N}\right)$. In June 1997, 2 paddocks each of 1 ha were sown with $10 \mathrm{~kg} /$ ha of either birdsfoot trefoil (L. corniculatus, var. Norcen) or white clover (Trifolium repens, var. Undrom). Timothy grass (Phleum pratense, var. Motim) was sown with $5 \mathrm{~kg} / \mathrm{ha}$ with each of the legumes. To reduce problems with weeds, the pasture leys were undersown with barley, which was cut for silage in late July. Estimates made in October showed that the pasture sown with $L$. corniculatus was covered to approximately $55 \%$ of this plant and the adjacent paddock contained $95 \%$ of $T$. repens. The remainder of the swards was largely Phleum pratense.

In June 1998 the timothy grass was cut to a height of approximately $8 \mathrm{~cm}$ on the $L$. corniculatus field. Half of both paddocks were cut in the middle of July. The harvest for the experiment then started on the uncut parts. Harvesting of whole crop (not chopped) was made every morning for the daily requirement and then fed immediately to the lambs. In the last 3 weeks of the experiment, the pasture that was initially cut was used for the study. 


\section{Experimental lambs}

Thirty six female crossbred lambs $(60 \%$ White Swedish Landrace, $40 \%$ Texel), born indoors with mean birth date 4 April 1998, were used in this trial. Mean birth weight was $4.2 \mathrm{~kg}$. Lambs were kept together in a common group with their dams and apart from suckling were offered ad libitum hay, concentrates, sheep mineral mix and water. The lambs were given a multivalent vaccination against clostridial infections on 2 occasions when approximately 5 and 10 weeks of age. They were weaned at approximately 2 months of age, 2 weeks after the first parasite infection (see below), and kept in the straw-bedded pens throughout the summer. The mean weight of the lambs during the 6week feeding experiment was $29 \mathrm{~kg}$ and they were approximately 3 months old at the start of the study.

\section{Parasite isolate}

Faecal collections were made from lambing ewes raised on several organic sheep farms located in southern Sweden during April/May 1998. Bulk cultures of this faecal material were made to provide a source of infective larvae for the trial. After 14 days incubation at $25^{\circ} \mathrm{C}$, infective larvae were recovered and differential identification showed the following distribution of species: Haemonchus contortus $\approx 10 \%$, Trichostrongylus $s p p \approx 20 \%$, Ostertagia $s p p \approx$ $60 \%$, Strongyloides papillosus $\approx 5 \%$, Oesphagostomum spp. $\approx 5 \%$.

The infective larvae were stored in small volumes of water in tissue culture flasks, laid on their side and stored at $5^{\circ} \mathrm{C}$, the water was replaced every fortnight.

\section{Experimental design}

Lambs were weighed 13 May and on the basis of weight, a stratified random allocation into 6 groups of 6 animals was made. The experimental treatments were accordingly:
Group LCA - Lotus corniculatus. Adult worm burdens only.

Group LCAL - Lotus corniculatus. Adult worm burdens + incoming larvae

Group LCL - Lotus corniculatus. Incoming larvae only

Group TRA - Trifolium repens. Adult worm burdens only

Group TRAL - Trifolium repens. Adult worm burdens + incoming larvae

Group TRL - Trifolium repens. Incoming larvae only

All groups were housed in separate pens. Lambs in A and AL groups received infective larval doses consisting of 1,000 infective larvae (L3), 3 times per week for 2 weeks, commencing 18 May, when the lambs were approximately 7 weeks old. Larval numbers were accurately estimated in the bulked aqueous suspension and administered to each restrained lamb with the use of a repeating dose syringe fitted with an oral dosing attachment designed for lambs. Between dosing of each lamb, the larvae contained within the syringe were kept in a uniform suspension by continuous inversion of this apparatus.

Three weeks after the last dose of larvae was given to the above 4 groups, all animals were offered freshly cut pasture, either containing $L$. corniculatus or $T$. repens, in accordance with their respective group assignment. The lambs had 2 weeks of slowly adapting to the fresh forage before the 6-week study (6 July - $16 \mathrm{Au}$ gust), when daily consumption in each group was estimated by weighing feeding rations and residues.

Faecal samples were collected from all lambs in A and AL groups, commencing 3 weeks after the start of the larval dosing, for estimates of nematode faecal egg count and larval cultures using standard parasitological procedures. This was then repeated every second week during the experiment. 
Table 1. Nutrient content of the fresh forages in the 6-week feed experiment. The $T$. repens ley includes the extra grass fed.

\begin{tabular}{lccc}
\hline & $\mathrm{DM}, \%$ & $\mathrm{CP}, \mathrm{g}$ & $\mathrm{ME}, \mathrm{MJ}$ \\
\hline $\begin{array}{l}\text { L. corniculatus ley, } \\
\text { week 1-3 }\end{array}$ & 21.5 & 96 & 10.0 \\
$\begin{array}{l}\text { L. corniculatus ley, } \\
\text { week 4-6 }\end{array}$ & 19.6 & 106 & 10.9 \\
$\begin{array}{l}\text { T. repens ley, } \\
\text { week 1-3 }\end{array}$ & 21.2 & 87 & 10.3 \\
$\begin{array}{l}\text { T. repens ley, } \\
\text { week 4-6 }\end{array}$ & 16.1 & 126 & 10.6 \\
\hline
\end{tabular}

Three weeks after the start of the feeding experiment (27 July), lambs in AL and L groups were given infective larvae, according to the same schedule and dose rate as outlined above. Feeding of the 2 different pasture types continued for 10 days after the last infection, then all lambs were sent for slaughter to the district abattoir (18-19 August). Viscera were collected and processed for worm recovery, speciation and enumeration by the methods described by Donald et al. (1978) and the mucosal digestion procedures of Dobson et al. (1990a).

\section{Feeding and feed analyses}

The lambs were fed twice a day. The rations varied between 3.2 and $4.8 \mathrm{~kg}$ fresh forage per lamb per day. Apart from this the lambs also re-
Table 2. Total feed intake (fresh forage plus hay), per animal per day, expressed as dry matter, crude protein and metabolisable energy for lambs fed the two pasture types (LC - Lotus corniculatus ley; TR Trifolium repens ley) during the 6 week experimental period.

\begin{tabular}{lccc}
\hline & DM, $\mathrm{kg}$ & $\mathrm{CP}, \mathrm{g}$ & $\mathrm{ME}, \mathrm{MJ}$ \\
\hline LC groups & 0.75 & 80 & 7.9 \\
TR groups & 0.76 & 67 & 8.0 \\
\hline
\end{tabular}

ceived $0.1 \mathrm{~kg}$ hay. They had free access to minerals, salt and water.

The botanical composition of the pastures was estimated once a week by taking samples from the cut forage, dividing into plant species, weighing and also measuring the dry matter content. Forage samples were collected daily and frozen for standard analyses of feed constituents, which were made in one-week periods. Samples also were analysed for condensed tannins using both the radial diffusion method (Hagerman 1987) and the HCl-butanol method (Porter et al. 1986).

\section{Statistical analysis}

The statistic programme SAS (1996) was used to calculate mean feed intake per group. For analysing lamb weights and worm counts the statistic programme NCSS 2000 was used, described by Hintze (1998). Variances were analysed with GLM-ANOVA.

Table 3. Intake of Lotus corniculatus and condensed tannins (CT) per animal per day in the L. corniculatus (LC) groups. Percentage of condensed tannins (CT) in the L. corniculatus during the experiment period.

$\begin{array}{ccc}\text { L. corniculatus } & \% \text { CT in } & \text { g CT consumed } \\ \text { consumed, } \mathrm{kg} \mathrm{DM} & \text { L. corniculatus }\end{array}$

\begin{tabular}{lccc}
\hline $\begin{array}{l}\text { Week 1-3 } \\
1^{\text {st cut }}\end{array}$ & 0.089 & 0.73 & $\begin{array}{c}0.61 \\
\text { Week 4-6 }\end{array}$ \\
\begin{tabular}{l}
$2^{\text {nd }}$ cut \\
\hline
\end{tabular} & 0.14 & 0.83 & $0.1 \%$ of DM intake \\
\hline
\end{tabular}




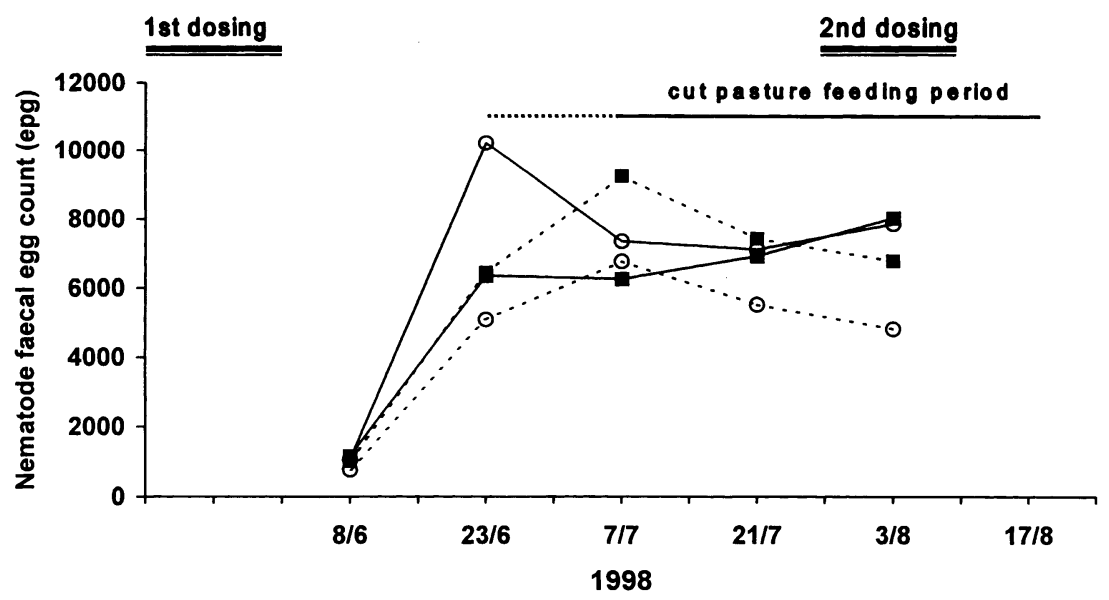

Figure 1. Nematode faecal egg counts of lambs fed 2 different forages at the time of having different levels of parasite burden and larval challenge.

$1^{\text {st }} / 2^{\text {nd }}$ Dosing: 1,000 infective larvae 3 times per week for 2 weeks

Feeding period: time when pasture swards offered (broken line $=$ adaptation period)

(solid line closed squares) LCA - L.corniculatus fed group with adult parasite burdens

(broken line closed squares) LCAL - L.corniculatus fed group with adult parasites + incoming infections

(solid line open circles) TRA - T. repens fed group with adult parasite burdens

(broken line open circles) TRAL - T. repens fed group with adult parasites + incoming infections

\section{Results}

\section{Feed Composition and Consumption}

The botanical composition of the 2 pasture leys differed considerably. The L. corniculatus grew slowly and the DM proportion of the plant in the pasture ley was only $15 \%(9 \%-23 \%)$ during the experiment. The other field contained $63 \%$ (35\%-78\%) of $T$. repens. The rest was mostly $P$. pratense. To provide the same proportion of legumes to all lambs, the latter rations was supplemented with fresh grass, mainly $P$. pratense, collected from another field. The two fresh forages fed to the lambs had similar contents, see Table 1.

The total consumption of nutrients is shown in Table 2. The figures are corrected for the amount and content of the residues. The figures are rather low, mostly due to the $P$. pratense, which tended to be too coarse to be palatable. The nutrient intake was sufficient to keep the lambs healthy, but not for weight gain. There were no differences in intake or weight change due to type of pasture.

The calculated intake of pure L. corniculatus is shown in Table 3 together with the results of the tannin analyses.

\section{Parasitology}

The faecal egg count results for the groups infected before the experiment are shown in Fig. 1. All the infected lambs had positive nematode faecal egg counts, which indicates that the larval dosing procedure was successful in all animals. There was no significant difference between groups having received different forages.

The result of the worm count data for the abomasal nematodes (H. contortus, Ostertagia spp. and T.axei) and the intestinal species (Trichostrongylus spp. and Cooperia spp.) is shown in 
Table 4. Mean nematode worm burdens in the abomasum and small intestine of lambs fed 2 different pasture forages and having different levels of parasite burdens and larval challenge.

\begin{tabular}{|c|c|c|c|c|c|c|c|c|}
\hline & LCA & LCAL & LCL & TRA & TRAL & TRL & $\begin{array}{c}\text { p-value } \\
\text { (Groups) }\end{array}$ & $\begin{array}{c}\mathrm{p} \text {-value } \\
\text { (LC vs TR) }\end{array}$ \\
\hline \multicolumn{9}{|c|}{ Abomasum } \\
\hline Adults & $825 \mathrm{~b}$ & $855 \mathrm{~b}$ & $117 \mathrm{a}$ & $750 \mathrm{~b}$ & $650 \mathrm{~b}$ & $100 \mathrm{a}$ & $<0.001$ & 0.10 \\
\hline dev. L4 & 11 & 53 & 25 & 0 & 0 & 25 & 0.25 & 0.13 \\
\hline Early L4 & 0 & 58 & 25 & 0 & 72 & 108 & 0.13 & 0.24 \\
\hline Total & $836 \mathrm{~b}$ & $967 \mathrm{~b}$ & $167 \mathrm{a}$ & $750 \mathrm{~b}$ & $722 \mathrm{~b}$ & $233 \mathrm{a}$ & 0.001 & 0.56 \\
\hline \multicolumn{9}{|c|}{ Ostertagia } \\
\hline Adults & $683 \mathrm{~b}$ & $639 \mathrm{~b}$ & $183 a$ & $675 \mathrm{~b}$ & $558 \mathrm{~b}$ & $133 \mathrm{a}$ & $<0.001$ & 0.68 \\
\hline dev. L4 & 17 & 86 & 25 & 0 & 89 & 108 & 0.24 & 0.48 \\
\hline Early L4 & $25 \mathrm{a}$ & 294 bc & $267 \mathrm{~b}$ & $33 a$ & $497 \mathrm{c}$ & $333 \mathrm{bc}$ & $<0.001$ & 0.25 \\
\hline Total & $725 \mathrm{ab}$ & $1019 b c$ & $475 \mathrm{a}$ & $708 \mathrm{ab}$ & $1144 \mathrm{c}$ & $575 \mathrm{a}$ & 0.016 & 0.61 \\
\hline \multicolumn{9}{|l|}{ T. axei } \\
\hline Adults & $167 \mathrm{ab}$ & $330 \mathrm{c}$ & $58 \mathrm{a}$ & $192 \mathrm{~b}$ & $394 \mathrm{c}$ & $75 \mathrm{a}$ & $<0.001$ & 0.50 \\
\hline dev. L4 & 0 & 8 & 25 & 8 & 17 & 8 & 0.72 & 1.00 \\
\hline Early L4 & 0 & 17 & 25 & 0 & 53 & 8 & 0.14 & 0.62 \\
\hline Total & $167 \mathrm{a}$ & $355 \mathrm{~b}$ & $108 \mathrm{a}$ & $200 \mathrm{a}$ & $464 \mathrm{~b}$ & $92 \mathrm{a}$ & $<0.001$ & 0.47 \\
\hline
\end{tabular}

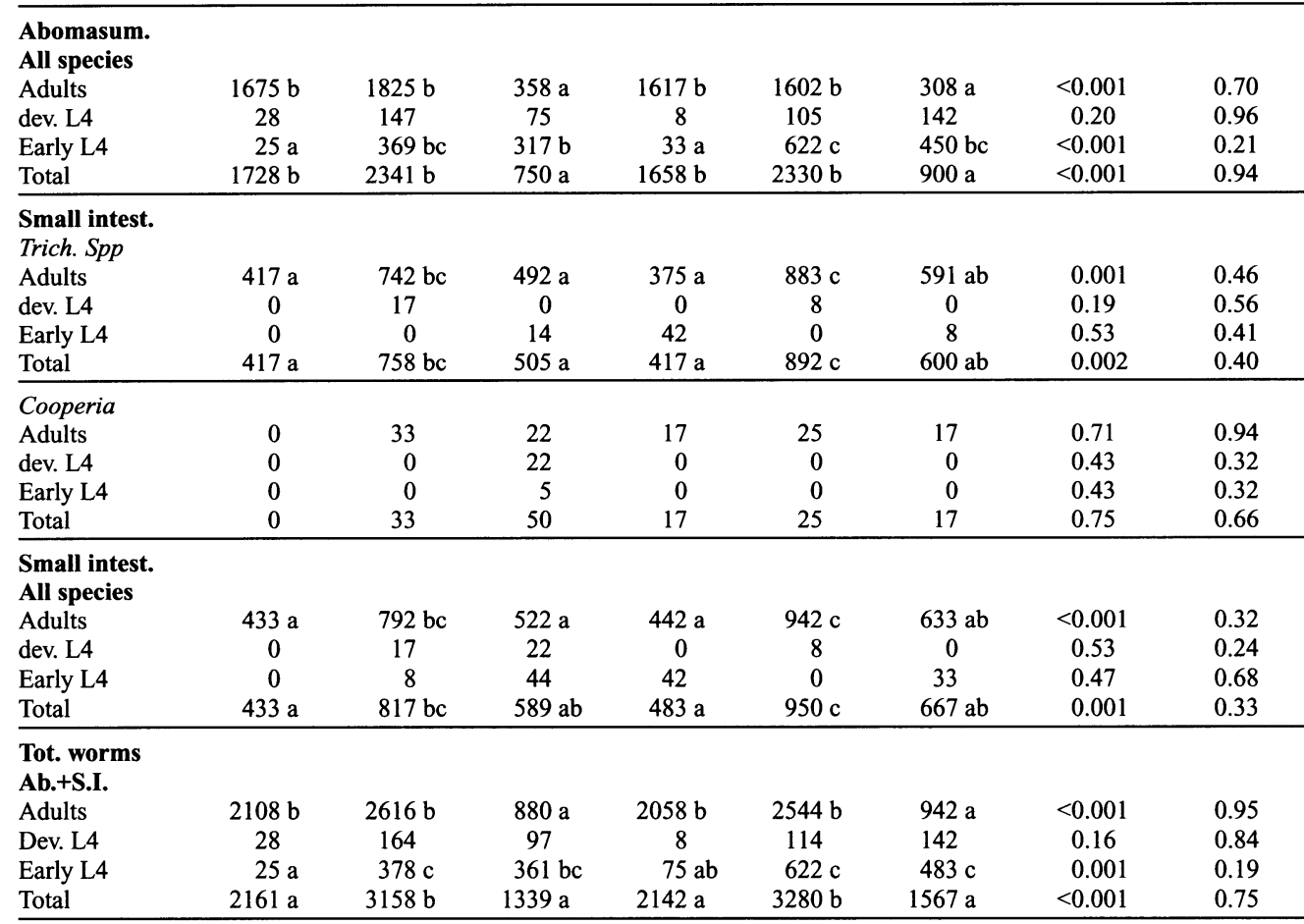

LCA - L.corniculatus fed group with adult parasite burdens. LCAL - L.corniculatus fed group with adult parasites + incoming infections. LCL $-L$. corniculatus fed group with incoming infections. TRA $-T$. repens fed group with adult parasite burdens. TRAL $-T$. repens fed group with adult parasites + incoming infections. TRL - T. repens fed group with incoming infections.

Probability levels of differences between LC and TR and also between each group, where figures on the same line with different letters are significantly different from each other at 0.05 prob. level. 
Table 4. Other minor species, as indicated in the differentiated infective larval doses, were recorded in very low numbers and thus are not provided in Table 4. Care was taken not only to differentiate between different parasite species, but also development stages (adult, developing fourth larval, and early fourth larval stages) for each species.

There were no consistent significant differences in worm burdens between LCA v's TRA, LCAL v's TRAL, LCL v's TRL indicating that there was no significant difference depending on the forage type. The differences between groups within forage were expected because the $2 \mathrm{AL}$ groups received twice the number of larvae (total $\approx 12,000 \mathrm{~L} 3$ ) as the $\mathrm{A}$ and the $\mathrm{L}$ groups (total $\approx 6,000 \mathrm{~L} 3$ ). In addition, the worm burdens of the $2 \mathrm{AL}$ groups approximate the sum of the A and the L groups for both pasture types.

\section{Discussion}

This study was designed to determine whether fresh pasture forage containing either L. corniculatus or T. repens had any differential effect on parasite species that occupy either the abomasum or the small intestine in young sheep. Also, any selective effects on either established worm burdens or on incoming infections could be estimated. This can be ascertained following the perusal of the detailed parasitological data provided in Table 4. We believe that it is important to not only provide data for the individual parasite species, but also to partition this information into different stages of parasite development. This is because the responses by the host to resident parasites and incoming infections, which can be influenced by a range of factors including diet, can vary between parasite species. Such manifestations include reduction in establishment rate, an increase in inhibited larval development (ie. less trafficking of larval stages from early fourth stage to adult para- sites), decrease in faecal egg count, which can precede the rejection of adult worm burdens. For a description of the differences in the dynamics of $H$. contortus, $O$. circumcincta and $T$. colubriformis parasite regulation in young sheep see Barger et al. (1985), Hong et al. (1987) and Dobson et al. (1990a, b, c, d), respectively.

The results indicate that, within the limitations of this study, no differential effect either within or between parasite species occurs when young sheep are fed these 2 pasture diets. However, rather than dismiss these results summarily, it is worthwhile reflecting on these in relation to the recent published information of the effect of temperate growing, tanniferous plants on the worm burdens of young sheep. This is because that although there has been considerable research activity in this field, the results are by no means clear-cut. Kahn \& Diaz-Hernandez (1999) critically reviewed the published information and concluded that the effects of condensed tannins may be attributed to the following factors in isolation or in combination:

1. Increases the supply and absorption of digestible protein, which indirectly improves host resistance and resilience to nematode parasite infections.

2. A direct anthelmintic effect on nematode parasite infections.

3. A direct effect on the viability of the freeliving stages of nematodes.

Although the initial hypothesis is intellectually appealing, there are considerable problems reconciling the published results with the time frame associated with the dynamics of acquired immunity of sheep to parasite infections and the benefits that are derived from improved nutrition. Acquired resistance to worm infections in sheep is a sequential process. For example with $T$. colubriformis infections, firstly this involves a decrease in the establishment rate of incoming larvae (Dobson et al. 1990a), fol- 
lowed by an increase in larval inhibition ( $D o b$ son et al. 1990b) and finally a decrease in fecundity of adult female parasites prior to expulsion of established worm burdens (Dobson et al. 1990c). The rate in which these processes proceed is governed by a complex range of interacting factors, including level of infection, age, nutrition, breed of the animal, but even with the most optimal set of circumstances, it is unlikely to be completed within 2 months (Dobson et al. 1990d). Increasing digestible protein has little effect on the early acquisition phase, but enhances the immune responses in the latter stages which generally does not become apparent until at least 2 months post infection (Abbott et al. 1985, Brown et al. 1991, van Houtert et al. 1995). Condensed tannins have $\mathrm{pH}$-dependent binding capabilities and associate with proteins between $\mathrm{pH} 4.0$ and 8.0 but dissociate below and above this interval (Jones \& Mangan 1977). Nutrition studies have shown that condensed tannins reduce protein degradation in the rumen and increase protein flow to the intestine where they can improve the supply and absorption of amino acids (Waghorn et al. 1994, Waghorn \& Shelton 1997). Therefore, although such beneficial effects may occur when parasitised young sheep are fed $L$. corniculatus, the 8 weeks ( 2 weeks adaptation +6 weeks trial) period of our study would have been an insufficient period of time to allow these effects to have become manifested. However, the same can be said for the studies in New Zealand by Niezen et al. 1994, 1995, 1998 (6, 6 and 5 weeks duration of these studies respectively) and Robertson et al. 1995 (6 weeks study). In these trials, production and parasitological benefits were reported in young sheep fed several tanniferous plants (esp. Hedysarum coronarium L. and L. pedunculatus), but not for L. corniculatus.

The lack of effect of $L$. corniculatus in our studies is in general accord with the New Zealand work cited above, but we believed $a$ priori that this was no reason why this plant species should not be tested under Swedish conditions. It is well known that the level of condensed tannins in plants varies not only with age and stage of development, but also with cultivars (Hedqvist et al. 2000). The content of condensed tannins in this experiment was approximately $0.8 \%$ of DM. Analyses have been made of the same cultivar, ie. Norcen, from different parts of Sweden and samples taken from different times of the season. The tannin content has varied between $0.4 \%-1.3 \%$ of the DM (Hedqvist 1999). Kelman \& Tanner (1990) found a variation between $0.1 \%-4.4 \%$ condensed tannins in $L$. corniculatus, depending on cultivar, location and condition of the soil. In a review article, Aerts et al. (1999) report tannin content of L. corniculatus between $2 \%-5 \%$ of DM. and L. pedunculatus to have levels ranging from $5 \%-10 \%$. L. corniculatus is one of the few tanniferous forages that can be cultivated as a perennial crop in Sweden, therefore deserving special research investigation under grazing conditions that prevail in the Swedish environment.

Also, we believe that the lack of any parasitological benefit of $L$. corniculatus, in contrast to L. pedunculatus (Robertson et al. 1995) is a paradox, particularly when compared to nutrition studies by the same group of workers (Waghorn et al. 1987, 1994). In the latter studies, L. corniculatus was shown to increase postruminal flows of protein and also increase intestinal absorption of amino acids. However, similar studies with $L$. pedunculatus showed that the greater post-ruminal flow of protein was negated by the lower absorption of amino acids in the small intestine and a greater loss of nitrogen in the faeces (Waghorn et al. 1987). Moreover, Waghorn et al. (1994) have shown that condensed tannins of $L$. pedunculatus, but not those of $L$. corniculatus, decrease the concentration of copper ions in rumen fluid and 
abomasal digesta. These 2 findings led Kahn \& Diaz- Hernandez (1999) to quite reasonably speculate that feeding sheep with $L$. pedunculatus may in fact increase, rather than decrease, their susceptibility to parasites.

Another possible reason for the lack of effect of L. corniculatus in our study was the relatively small component of this forage in the daily rations provided during the course of this trial. The amount of condensed tannins needed for optimum effect on protein digestion is $2 \%-5 \%$ of the DM (Waghorn et al. 1987, Aerts et al. 1999). In our study the final intake of tannins only was around $0.1 \%$ of the dry matter. A mixed pasture sward, rather than a pure stand of L. corniculatus, was deliberately selected for this work as this plant species is being promoted as a beneficial component in balanced perennial pasture mixes in Sweden (NilsdotterLinde et al. 1999). The species also has difficulties in establishing as a sole plant in a ley due to its slow growth in the spring, which makes it easy to be overgrown by weeds. This being the case, we believed that potential parasitological benefits needed to be assessed in relation to the agronomic recommendations for the use of this leguminous plant in Sweden.

It is conceded that the failure to elicit a parasitological response may not only be due to the fact that the feeding interval was insufficiently long. Also, the amount of condensed tannins may have been too low to detect the presence of any direct anthelmintic effect on worm burdens, or ovicidal/larvacidal effects in faeces. Molan et al. (1999) provide evidence that condensed tannins extracted from a range of temperate growing forages, which included $L$. corniculatus, decrease the translation of nematode eggs to infective larvae and the motility of these latter stages. Although no in vitro ovicidal/larvacidal studies were conducted on the effect of the condensed tannins extracted from the $L$. corniculatus cultivar used in this study, cultures of faeces from lambs fed $L$. corniculatus yielded comparable numbers of infective larvae as those from lambs fed $T$. repens.

\section{Acknowledgements}

Competent technical assistance by Ms. B. Christensson, R-M. Klausson and J. Nordström is gratefully acknowledged. This project was financially supported by Skogs och Jordbrukets Forskningsråd (SJFR) and Jordbruksverket. It is part of a collaboration project entitled, "Studies in birdsfoot trefoil population ecology, protein efficiency and anti-parasitic effects in ruminants". We would like to thank our colleagues in this project Nilla Nilsdotter-Linde, Magne Tuvesson, Michael Murphy, Helena Hedqvist, Jan Jansson and Gunnar Danielsson for constructive discussions and conducting the tannin analyses (H.H. and M.M.).

\section{References}

Aerts RJ, Barry TN, McNabb WC: Polyophenols and agriculture: beneficial effects of proanthocyanidins in forages. Agriculture, Ecosystems and Environment 1999, 75, 1-12.

Abbott EM, Parkins JJ, Holmes PH: Influence of dietry protein on parasite establishment and pathogenesis in Finn Dorset and Scottish Blackface lambs given a single moderate infection of $\mathrm{Hae}$ monchus contortus. Res. Vet. Sci. 1985, 38, 6-13.

Barger IA, Le Jambre LF, Georgi JR, Davies HI: Regulation of Haemonchus contortus populations in sheep exposed to continuous infection. Int. J. Parasitol. 1985, 15, 529-533.

Beuselinck PR, Grant WF: Birdsfoot trefoil. In: Forages Volume 1: An Introduction to Grassland Agriculture (RF. Barnes, Miller DA. Nelson CJ. editors). Fifth Edition. Iowa State University Press, Ames, Iowa, USA. 1995. pp 237-248.

Brown MD, Poppi DP, Sykes AR: The effect of postruminal infusion of protein or energy on the pathophysiology of Trichostrongylus colubriformis infection and body compostion in lambs. Aust. J. Agric. Res. 1991, 42, 253-267.

Dobson RJ, Waller PJ, Donald AD: Population dynamics of Trichostrongylus colubriformis in sheep; the effect of infection rate on the establishment of infective larvae and parasite fecundity. Int. J. Parasitol. 1990a, 20, 347-352

Dobson RJ, Waller PJ, Donald AD: Population dynamics of Trichostrongylus colubriformis in 
sheep: the effect of host age on the establishment of infective larvae. Int. J. Parasitol. 1990b, 20, 353-357.

Dobson RJ, Waller PJ, Donald AD: Population dynamics of Trichostrongylus colubriformis in sheep; the effect of infection rate on loss of adult parasites. Int. J. Parasitol. 1990c, 20, 359-363.

Dobson RJ, Donald AD, Barnes EH, Waller PJ: Population dynamics of Trichostrongylus colubriformis in sheep; model to predict the worm population over time as a function of infection rate and host age. Int. J. Parasitol. 1990d, 20, 365-373.

Donald AD, Morley FHW, Waller PJ, Axelsen A, Donnelly JR: Availability to grazing sheep of gastrointestinal nematode infection arising from summer contamination of pastures. Aust. J. Agric. Res. 1978, 29, 189-204.

Hagerman $A E$ : Radial diffusion method for determining tannin in plant extracts. J. Chem. Ecol. 1987, 13, 437-449.

Hedqvist $\mathrm{H}$ : Kondenserade tanniner i käringtand ( $\mathrm{Lo}$ tus corniculatus L.) - kvantifiering, karaktärisering samt in vitro studier av deras effekt på proteinnedbrytning i vommen (Condensed tannins in birdsfoot trefoil (Lotus corniculatus L.) - quantification, characterization and in vitro studies of their effect on protein degradation in the rumen). 1999. Examensarbete 116, inst. för husdjurens utfodring och vård, SLU.

Hedqvist H, Mueller-Harvey I, Reed JD, Krueger $C G$, Murphy $M$ : The tannins and in vitro digestibility of seven Lotus corniculatus varieties. Anim. Feed. Sci. Techn. 2000. (in press).

Hintze J: NCSS 2000. Manual. 1998. Kaysville, Utah.

Hong C, Michel JF, Lancaster MB: Observations on the dynamics of worm burdens in lambs infected daily with Ostertagia circumcincta. Int. J. Parasit. 1987, 17, 951-956.

Jones WT, Mangan JL: Complexes of condensed tannin of sanfoin (Onobrychus vicifolia Scop) with fraction 1 leaf protein and with submaxillary mucoprotein, and their reversal by polyethylene glycol and pH. J. Sci. Food. Agric. 1977, 28, 126136.

Kahn LP, Diaz-Hernandez A: Tannins with anthelmintic properties. International Workshop on Tannins in Livestock and Human Nutrition. Waite Campus, University of Adelaide. 1999. ACIAR Proceedings No 92, 1999, 130-139.

Kelman WM, Tanner GJ: Foliar condensed tannin levels in lotus species growing on limed and un- limed soils in South-Eastern Australia. Proc. N.Z. Grassland Assoc. 1990, 52, 51-54.

Lowther WL, Manley TR, Barry TN: Condensed tannin concentrations in Lotus corniculatus and Lotus pedunculatus cultivars grown under low soil fertility conditions. N.Z. J. Agric. Res. 1987, 30, 23-25.

Molan AL, Waghorn GC, McNabb WC: Condensed tannins and gastro-intestinal parasites in sheep. Proceedings of the New Zealand Grassland Association. 1999, 61, 57-61.

Niezen JH, Waghorn TS, Raufaut $K$, Robertson $H A$, $M c F a r l a n e ~ R G$ : Lamb weight gain and faecal egg count when grazing on of seven herbages and dosed with larvae for six weeks. Proc. NZ Soc. Anim. Prod. 1994, 54, 15-18.

Niezen JH, Waghorn TS, Charleston WAG, Waghorn $G C$ : Growth and gastrointestinal nematode parasitism in lambs grazing either lucerne (Medicago sativa) or sulla (Hedysarum coronarium) which contains condensed tannins. J. Agric. Sci. Camb. 1995, 125, 281-289.

Niezen JH, Waghorn GC, Charleston WAG: Establishment and fecundity of Ostertagia circumcincta and Trichostrongylus colubriformis in lambs fed lotus (Lotus pedunculatus) or perennial ryegrass (Lolium perenne). Vet. Parasitol. 1998, 78, 13-21.

Nilsdotter-Linde $N$ : Birdsfoot trefoil grown in mixtures with grasses in a temperate climate. In Organic agriculture the credible solution for the XXIst century. (D. Fougelman \& W. Lockeretz editors). Proceedings of the 12th international IFOAM scientific conference. November 15th19th 1998. Mar del Plata, Argentina, 1999, pp.171-175.

Nilsdotter-Linde N, Tuvesson M: Samodlingskomponenter till käringtand (Lotus corniculatus L.) (Companion plants to birdsfoot trefoil (Lotus corniculatus L.). SLU. Centrum för uthålligt lantbruk. Konferens Ekologiskt lantbruk, Alnarp, 8-10 november 1999. Sammanfattningar av föredrag och postrar, 173-174.

Nilsdotter-Linde N, Bernes G, Christensson D, Jansson J, Murphy M, Tuvesson M: Tar käringtanden klivet ut på åkern? - populationsekologi, proteinutnyttjande, parasitpåverkan (Does birdsfoot trefoil take the step out into the field? - population ecology, protein utilization, effect on parasites). SLU. CUL. Ekologiskt lantbruk 10-13 mars 1998. Konferensrapport. Ekologiskt lantbruk 1999, 28, 142-143. 
Porter $L W$, Hrstich $L N$, Chan BG: The conversion of procyanidins and prodelphinidins to cyanidin and delphinidin. Phytochemistry. 1986, 25, 223-230.

Robertson HA, Niezen JH, Waghorn GC, Charleston $W A G$, Jinlong M: The effect of six herbages on liveweight gain, wool growth, and faecal egg count of parasitised ewe lambs. Proc. NZ. Soc. Anim. Prod. 1995, 55, 199-201.

SAS: SAS System for Windows, version 6.12. User's guide; Statistics. 1996. SAS Institute Inc., Cary, NC.

Tanner GJ, Moate PJ, Davis LH, Laby RH, Yuguang L, Larkin PJ: Proanthocyanidins (condensed tannin) destabilise plant protein foams in a dose dependent manner. Austr. J. Agric. Res. 1995, 46, 1101-1109.

Van Houtert MFJ, Barger IA, Steel JW, Windon RG, Emery $D L$ : Effects of dietary protein intake on responses of young sheep to infection with Trichostrongylus colubriformis. Vet. Parasitol. 1995, 56, 163-180.

Waghorn GC, Ulyatt MJ, John A, Fisher MT: The effect of condensed tannins on the site of digestion of amino acids and other nutrients in sheep fed on Lotus corniculatus L. British J. Nut. 1987, 57, 115-126.

Waghorn GC, Shelton ID, McNabb WC, McCutcheon $S N$ : Effects of condensed tannins in Lotus pedunculatus on nutiritive value for sheep. 2. Nitrogenous aspects. J. Agric. Sci. Camb. 1994, 123, 109-119.

Waghorn GC, Shelton, ID: Effect of condensed tannins in Lotus corniculatus on the nutritive value of pasture for sheep. J. Agric. Sci. 1997, 128, 365-372.

\begin{abstract}
Sammanfattning
Effekt av betesvall innehållande käringtand (Lotus corniculatus L.) eller vitklöver (Trifolium repens L.) på inkommande och etablerade parasitinfektioner hos unga lamm.
\end{abstract}

Käringtand, Lotus corniculatus L., är en baljväxt som på senare år rönt ökat intresse som betesväxt, $\mathrm{bl} \mathrm{a}$ grundat på dess innehåll av kondenserade tanniner (CT). Målet med föreliggande experiment var att studera om växten genom sitt CT-innehåll har någon antiparasitär effekt på parasitinfekterade lamm. Tre månader gamla lamm utfodrades dagligen under 6 veckor med olika grönfoderblandningar, antingen bestående av L. corniculatus och Phleum pratense (timotej) eller som jämförelse en CT-fri blandning av Trifolium repens L. (vitklöver) och timotej. Baljväxtandelen i foderstaten var i medeltal $15 \%$ och intaget av CT från käringtandblandningen var ca $0,1 \%$ av dagligt torrsubstansintag. Grupper om 6 lamm på varje foderstat infekterades med totalt 6000 infektiösa L3-larver av Ostertagia, Haemonchus cont. $\mathrm{m} \mathrm{fl}$ arter. Lammen infekterades antingen en månad före utfodringens början eller under senare delen av utfodringsperioden eller vid båda tillfällena. Utskiljningen av trichostrongylida ägg per gram träck (epg) registrerades varannan vecka genom individuella träckprov. Efter utfodringsperiodens slut slaktades samtliga lamm och etablerade parasiter i löpmage och tunntarm räknades och artbestämdes. Det förelåg inga signifikanta skillnader mellan de lamm som fătt L. corniculatus och de som fătt $T$. repens, varken vad beträffar parasiternas artsammansättning eller utvecklingsstadiernas fördelning. Resultaten av denna undersökning visar inte på någon parasithämmande effekt hos käringtand.

(Received March 21, 1999; accepted August 16, 2000).

Reprints may be obtained from: P.J. Waller, Department of Parasitology (SWEPAR), National Veterinary Institute, SE-751 89 Uppsala, Sweden. E-mail: Peter.waller@sva.se, Tel: +46 186741 27, fax: +46 18309162. 